\section{DIGITAL COMMONS \\ @ UNIVERSITY OF SOUTH FLORIDA}

\section{ABO: Interactive Journal for Women in the Arts, 1640-1830}

Volume 9

Issue 1 Special Issue: Eighteenth-Century Camp

Article 7

2019

\title{
Mansfield Park by Kate Hamill (and Jane Austen)
}

Christopher Nagle

Western Michigan University, cnagle@wmich.edu

Follow this and additional works at: https://digitalcommons.usf.edu/abo

Part of the Dramatic Literature, Criticism and Theory Commons, Educational Methods Commons, Feminist, Gender, and Sexuality Studies Commons, and the Literature in English, British Isles Commons

\section{Recommended Citation}

Nagle, Christopher (2019) "Mansfield Park by Kate Hamill (and Jane Austen)," ABO: Interactive Journal for Women in the Arts, 1640-1830: Vol.9: Iss.1, Article 7.

https://doi.org/10.5038/2157-7129.9.1.1211

Available at: https://digitalcommons.usf.edu/abo/vol9/iss1/7

This Reviews is brought to you for free and open access by Digital Commons @ University of South Florida. It has been accepted for inclusion in ABO: Interactive Journal for Women in the Arts, 1640-1830 by an authorized administrator of Digital Commons @ University of South Florida. For more information, please contact digitalcommons@usf.edu. 


\title{
Mansfield Park by Kate Hamill (and Jane Austen)
}

\author{
Abstract \\ This article reviews the world premiere of Kate Hamill's Mansfield Park directed by Stuart Carden and \\ produced for the Northlight Theatre in Chicago in November and December 2018. Hamill's bold new \\ adaptation is notable for foregrounding the contexts of empire and the slave trade undergirding the novel, \\ and in ultimately offering a feminist fairy-tale of radical self-assertion and self-determination for its \\ heroine.

\section{Keywords} \\ Jane Austen, adaptation, \#BlackLivesMatter, empire, farce, feminism, \#MeToo, slavery \\ Creative Commons License \\ (c) (1) (8)
}

This work is licensed under a Creative Commons Attribution-Noncommercial 4.0 License

\section{Cover Page Footnote}

I would like to thank Briana Asmus and Aleksondra Hultquist for especially generous and helpful feedback. 
Mansfield Park by Kate Hamill (and Jane Austen)

Northlight Theatre, Chicago, November-December 2018 / Dir. Stuart Carden

Reviewed by Christopher Nagle

Western Michigan University

If this review were to have a title it would be "Everything Is Tainted," the overarching theme as I take it of this splendid, disturbing production. Another way of putting it: despite the play's arrival in Regency-inspired costuming during the holiday season, this is no "Christmas at Pemberley" confection designed For the Whole Family. In something of a reversal of that old saw from Marx-in which history is repeated, events occurring first as tragedy and the second as farce-Kate Hamill's new adaptation of Jane Austen's dark, experimental problem novel, Mansfield Park, divides itself into two starkly opposed acts: the first is comedy, with pronounced elements of farce; the second is drama heightened with tragic undertones. What it is not, though, is tragi-comedy, at least not in the familiar form one might imagine after Beckett, Pinter, Stoppard \& Co. Rather, the two acts sit uncomfortably next to each other, ultimately suggesting something familiar - that these elements are enduring aspects of human existence - and perhaps also something surprising - that the tale by which we have been absorbed for two hours is also both things, and that we should have been able to anticipate this shift from light to dark. We might even be left to wonder if we did see it all along - both the dark implications and the crisis to which the play leads - but simply did not want to. Have we become complicit like the characters themselves, getting caught up in the fine estate, clothes, manners, company, and domestic entertainment?

Were that true, it would not be because audience members all came knowing how Austen's novel works out. Surely such audiences are rare, limited perhaps to special performances for one of the many global Jane Austen societies. And this makes the playwright's achievement all the more remarkable. Hamill has proven herself to have a rare gift for drawing in audiences to literary adaptation, enjoying nation-wide success as one of the most produced playwrights in the U.S. for two years running, earning the Wall Street Journal's Best Playwright of 2017, and thus emerging as one of the current theater world's hottest commodities. Watching this powerful, dynamic production, sensitively directed by Stuart Carden and featuring a dream cast of local talent, makes it very clear why this is so. Not only does Hamill always assiduously avoid the slavishness of cut-and-paste adaptation, but she also alters, removes, or creatively distorts most everything that could be predictable about a period piece first published in 1814. In this world premiere of her newest play, she deviates even further than she has to date from the Austenian source-text. As in her other work, it might be described best as "period- 
adjacent"— costumes and sets are mostly suggestive of the period, with liberties taken to avoid being too fussy and precise - and the story itself reflects the kind of collaboration-with-a-dead-author that Hamill often mentions in interviews about her craft.

Some recognizably Hamill-tonian features are immediately apparent in Act One: actors play multiple characters, with the exception of the two leads, Fanny (Kayla Carter) and Edmund (Gabriel Ruiz); elements of farce are prominent, including over-the-top portrayals of a Rushworth (Curtis Edward Jackson) so enthusiastic and pratfall-prone that he seems to be on methamphetamines, and a consistently semi-conscious Lady Bertram (Hamill, in perhaps her best of three wonderful roles, including Mary Crawford and Chapman the servant). Lady Bertram is attached quite literally to her "pug," which is actually her brown muff converted into a puppet dog who barks ferociously enough to compete with the characters' dialogue. All of this business is great fun, and helps to underscore the theatricality of Austen's novel, which famously features a highly fraught amateur rehearsal of the racy 1798 hit, Lover's Vows (itself a foreign import, translated by another remarkable contemporary of Austen, Elizabeth Inchbald). When staged, we are treated to a metatheatrical play-within-a-play, which of course functions differently on stage than it does in Austen's source text. While a separate essay could be written about this element alone, suffice it to say that such hypertheatricality should provoke the audience to recollect that all action within the world of the play (and perhaps in our own as well) is staged in ways both more and less obvious.

The pacing of the first act is also typically frenetic much of the time, although punctuated by some beautiful and well-timed scenes of authentic tenderness and feeling: two that stand out especially are Edmund's first visit to young Fanny's room, attempting to befriend and console her early after her disorienting arrival at Mansfield, and Tom's warning to Fanny as she prepares to leave Mansfield for her former squalid home in Portsmouth that "everything - and everyone - is tainted" in this posh, privileged Bertram estate. In both scenes the actors subtly convey nuances of character, and the emotional connections developing between Fanny and each of these very different cousins is palpable. So if characters are often galloping around the stage, and wheeling set pieces to and fro-and even mixing elements of traditional period dance with contemporary stylings of music and movement (as they do during the ball held for Fanny at Mansfield) - there are also pitch-perfect moments in the turbulent affective life of Mansfield Park to anchor the story in a shared humanity that never totally disappears. 
Nearly all of this landscape changes radically in Act 2, both in tone and setting. No more crazed capering by Rushworth, Lady Bertram falling off the sofa, and Pug-the-puppet combining to provide centerstage farcical hijinks. To be fair, the first act ends with Tom's breakdown and literal collapse on the floor, center stage and in the middle of the glittering Mansfield ball, while above the din the imperious Sir Thomas (Mark Montgomery) abusively commands Fanny to "Smile!" This scene sets us up for the drama of Fanny's refusal of the delightfully flirtatious Henry Crawford (Nate Burger) and Sir Thomas's subsequent exile of Fanny to Portsmouth in the second act, which focuses on the tragedy of life in Portsmouth and the comparative farce of life at Mansfield. But these oppositions cannot be maintained and are not meant to be. Neither place, her birthplace nor her adopted home, are life-affirming for Fanny; in contrast to each other, each seems a bit surreal, and the play allows neither to be idealized-perhaps partly because the stage removes us from the rich inner life of Fanny's mind that features so prominently in the novel. Yet it is still Fanny's tale, to be sure, and when she solemnly repeats to herself variations of "I will learn," we are reminded that this story is also a kind of female bildungsroman.

Here and elsewhere one feels the substantial debt to Patricia Rozema's controversial 1999 film. Both of Rozema's primary deviations (apart from matters of plot) are central to Hamill's play as well: the foregrounding of the novel's uglier historical contexts, particularly the slave trade- "who pays for this party," as Tom Bertram memorably underscores this theme in the film-and the recasting of Fanny Price as a recognizably feminist heroine, amplified for a contemporary audience that struggles to imagine a strong heroine without seeing her lash out in protest of the injustice around her and unambiguously assert her independence. Both innovations respond to matters discussed and debated repeatedly in Austen circles, both amateur and professional, without any clear consensus. Perhaps nothing more quickly divides a room of Janeites than the question of "creepmouse" Fanny Price (admire her or detest her?) or the question of Austen's perceived intentions regarding the Bertrams' Antigua property (abolitionist or apologist?), even decades after the signal feminist and postcolonial interrogations in the world of Austen literary criticism. Anyone adapting this work now simply cannot avoid addressing these questions.

The Northlight production of Hamill's play does not resolve these ongoing debates, but it surely restores them to their centrality while transforming their terrain to the stage. When this Fanny tells off the whole family before returning of her own volition to a Portsmouth she claims as morally superior to Mansfieldfollowed eventually by a creep-mouse Edmund who announces that he has been disowned by his father and now begs acceptance from his beloved cousin-we 
have certainly entered into a brave new Mansfield Park. Whatever transpired among the Bertrams after Fanny's departure is left a mystery to us and essentially rendered irrelevant. After she sets everyone straight about their shared hypocrisy, we see and think of them no more, as we imagine to be true of our heroine. Fanny is not only the moral center of the play, its sole measure of virtue, she is also the lone uncompromised character: disappointed in Edmund's frailty, immediately perceiving Henry Crawford's duplicity, resistant even to the charms of his seductive sister Mary - none of the flaws Fanny shows in the novel emerge here. Perhaps most striking of all, Austen's most unsettled and generally unsatisfying of endings resolves neatly in Hamill's play, with Fanny kissing Edmund in the final scene and their happy embrace in Portsmouth leaving all of Mansfield-people, property, and pug - far behind, presumably forever.

What Would Jane Think? Perhaps there is a better question for Austen fans and scholars - and for historians of the slave trade and abolition - that Hamill's adaptation invites us to consider: what stories do we want to hear (and see)? Who benefits - and how do they benefit - from telling only narrowly "traditional" tales versus tales that uncover new layers, new truths, new perspectives on what we think we already know? The point seems to me to lie precisely in the thinking: every story, Austen's included, is partial. Rich, challenging, even transformative, perhaps, but still: partial. There is no such thing as a "complete" narrative - when we tell stories, whether based on truths or not, choices are made, and elements are necessarily left out while others are included. What Hamill's retelling of Mansfield Park shows us more than anything else, perhaps, is that the stakes are much higher when a tale is woven from ugly and difficult materials, contested even in 1814, and surely not resolved two centuries later in the era of \#MeToo, \#BlackLivesMatter and the various \#Decolonizing initiatives for museums, monuments, and knowledge more broadly.

Northlight's visionary production, brilliantly lit, constructed, costumed, directed and performed, sets us up to encounter this disturbing, experimental Austen work anew (the program notes include a statement by Hamill on the choice of the novel and one on Austen as a kind of abolitionist) in these respects and others as well. As the playwright herself clearly believes, we still need the classics, as we always have. And we also need them recast, reimagined - as we always have. Three cheers for this breathtaking, remarkable, stunningly brave new play, which is every bit as much Jane Austen as it is Kate Hamill. As it is all of us-then and now, light and dark, tainted to the core (which is to say: human), but never wholly devoid of hope for better days. Let other pens dwell on guilt and misery, as Austen says in the end-Hamill has given us something far beyond both, and far better. 